\title{
ENIGE AANTEKENINGEN OMTRENT DE ONTWIKKELING VAN ,AULITING PROCEDURES AND STANDARDS” IN AMERIKA
}

\author{
door D. P. Portey
}

In het nummer van September 1950 van .,The Journal of Accountancy" geeft de Heer Alvin R. Jennings, destijds voorzitter van het Committee on Auditing Procedure van het American Institute of Accountants, een zeer lezenswaardige uiteenzetting van de ontwikkeling in de ,Auditing Procedures and Standards" in Amerika. De hoofdinhoud van het artikel moge met het volgende onder de aandacht van de lezer worden gebracht.

Schrijver begint met er op te wijzen dat veranderingen in "accounting principles" van belang zijn zowel voor de accountant als voor de cliënt. Dit geldt in mindere mate voor veranderingen in de contrōle techniek; hiervan ziet de cliënt het belang niet zo direct in en het is dus logisch dat deze veranderingen niet in dezelfde mate de aandacht trekken. Het beantwoorden van de vraag of van beroepsstandpunt uit bezien, op het gebied van de contrōle vooruitgang te constateren valt, vereist een beschouwing in grote lijn van het doel van ons werk.

Aangezien de vooruitgang op dit gebied een zekere cumulatieve groei vertoont, is het noodzakelijk, een duidelijk beeld voor ogen te hebben van het doel dat we willen bereiken en voortdurend vooruit te zien, al zullen we niet kunnen nalaten van tijd tot tijd even een blik in het verleden te werpen, omdat ook de gedaante van het verleden de toekomst mede helpt bepalen. Het American Institute of Accountants (A.I.A.) telde in September 1950 plm. 15000 leden d.i. $\pm 40 \%$ van het totaal aantal ,certified public accountants". Hiervan waren meer dan 1000010 jaar of korter lid. Een groot deel hiervan oefent de practijk uit in kleinere plaatsen. Deze snelle groei brengt vele problemen mede die niet onderschat mogen worden.

De twee niet hoog genoeg te waarderen actiefposten van de accountant $z$ ijn, zijn onafhankelijkheid en zijn recht om zijn persoonlijk oordeel uit te spreken binnen de grenzen van de daarvoor algemeen erkende normen. Er kan hier geen dualistisch standpunt, als zouden er normen kunnen zijn voor grote en kleine kantoren, worden ingenomen. De grote kantoren en de leden met grotere ervaring moeten het waarderen, dat ze meer dan ooit een beroepsplicht hebben tegenover de kleinere kantoren, door deze te tonen hoe de verbeterde ",auditing standards" met succes overal kunnen worden toegepast.

Het accountantsberoep is, evenals elk persoonlijk beroep, gevoelig voor de veranderingen in de behoefte van degene die van de diensten die dat beroep kan bieden, gebruik maken.

De aard van de behoefte bepaalt de dienst die wij zullen moeten bewijzen en het is dus logisch dat we beginnen met te overwegen, welke soorten diensten wij kunnen bewijzen. Niettegenstaande het beroep in Amerika op grotere schaal reeds sinds meer dan een halve eeuw wordt uitgeoefend, is men het over de classificatie van de diensten die de accountants bewijzen, nog niet eens geworden. Dit is een reëel nadeel. Iedereen weet dat er "contrôles" en .,contrôles" zijn, maar het woord is veel te algemeen om hier van practisch nut te kunnen zijn. De meest belangrijke van de door accountants verrichte contrôles is die welke 
resulteert in een oordeel met betrekking tot de jaarrekening. Schrijver noemt dit „financial examinations". Het belang van deze contrōles is de laatste halve eeuw sterk toegenomen. Als oorzaak hiervan wijst schr. op de groei van de ondernemingen, hetgeen vergezeld is gegaan van de spreiding der aandelen, waardoor de contrōle door de eigenaren zelf middels het actief deelnemen aan de leiding, niet langer mogelijk was. Deze leiding kwam in handen van "beroepsleiders" die slechts een bescheiden aandelen belang hadden. Vroeger, en ook thans nog in de kleinere ondernemingen, werd een belangrijk deel van de interne contróle door de eigenaren zelf verricht. Door de groei van de ondernemingen, werd het noodzakelijk een deel hiervan aan anderen over te laten en naarmate de onderneming groter werd, kon deze contröle meer geperfectioneerd worden. Met deze verandering ging gepaard een verandering in de aard van de diensten van de public-accountant. De afwezigheid n.l. van een goed systeem van interne contrỏle bij de kleinere ondernemingen vereiste dat de accountant een min of meer gedetailleerde controle instelde om zich een redelijk oordeel over de jaarrekening van de onderneming te kunnen vormen. Naarmate de interne contrôle maatregelen in de onderneming zelf toenamen, begon de taak van de externe accountant op dit gebied in omvang af te nemen. Onder deze omstandigheden acht schrijver een "more detailed type of examination" door de public accountant bij de grotere ondernemingen niet langer vereist.

Een goede dekking tegen eventuele verliezen voortspruitende uit onregelmatigheden heeft altijd berust op een of andere combinatie van de volgende drie dingen, n.l.;

1. interne contrōle,

2. fraude verzekering,

3. het werk van de public accountant.

Hoewel deze drie punten steeds hebben bestaan, is er een belangrijk verschil tussen nu en vroeger wat het relatieve belang van elk dier 3 punten betreft. Fraude contrôle is thans in eerste instantie de taak van de interne contrôle. Het feit dat fraudes van tijd tot tijd door de public accountant worden ontdekt, verandert hieraan niets.

Dat het begrip voor wat tot de eigenlijke taak van de accountant behoort bij het uitvoeren van "financial examinations" de laatste jaren sterk is toegenomen, meent schr. te mogen concluderen uit het feit dat in December 1945 een aantal grotere verzekerings-ondernemingen zich tegenover het A.I.A. bereid hebben verklaard, de schade te vergoeden waarvoor de leden aansprakelijk gesteld zouden kunnen worden, mits deze schade niet voortvloeit uit oneerlijke of misdadige handelingen of grove nalatigheid van de leden zelf. Een onpartijdige commissie zal over dit laatste oordelen.

Anderzijds wijst schr. er op dat een juist begrip omtrent de taak van de accountant zeker nog niet algemeen is en dat dit gebrek aan begrip mede voor een belangrijk deel aan de accountants zelf te wijten is. Men is n.l. te voorzichtig en te aarzelend in de discussies omtrent dit punt, hoewel een juist begrip van de taak van de public accountant bij de "financial examinations" toch van eminent belang is, zowel voor de cliënt als voor de accountant. Hij is van mening dat in vele contrôle programma's van accountants nog veel wordt opgenomen, niet omdat hiermede een werkelijke bijdrage wordt geleverd tot het vormen van het oordeel van de accountant, maar uit sleur of traditie. Het aannemen door de 
leden in 1948 van het speciale rapport „Tentative Statement of Auditing Standards" is van groot belang geweest. Hierin wordt voor het eerst een duidelijk onderscheid gemaakt tussen ".Auditing Standards" en „Auditing Procedures". Ik zou deze begrippen willen vertalen met "contrôle normen" en .,contrôle technieken".

De Auditing Standards worden verdeeld in 3 groepen n.l.:

a. "General standards" - deze betreffen meer de persoon van de accountant.

b. "Standards of field work" - deze betreffen de wijze van uitvoering der contrôle.

c. ..Standards of Reporting" - deze betreffen de wijze van rapporteren.

De studie van de "Auditing Standards" was in het .Committee on Auditing Procedure" de voorloper van de studie van de "Auditing Procedures". Bij deze laatste wordt niet uitsluitend de principiële kant in het oog gevat, doch speciale practische gevallen hebben mede de aandacht en leiden tot de publicatie van verschillende "case studies". Deze "case studies" kan men zien als een verbeterde voortzetting van "Examinations of Financial Statements bij Independent Public Accountants", een in 1936 verschenen publicatie van het A.I.A. Met de publicatie van deze geschriften verricht het "Committee on Auditing Procedure" belangrijk opvoedend werk. Tot September 1950 waren 8 ,case studies" verschenen waarvan er 7 betrekking hadden op grotere ondernemingen en 1 op een kleinere. Een vrij groot aantal was nog in bewerking. Hiervan hadden er een 3 tal betrekking op de samenwerking met de interne controle.

Het is niet zo dat op de niet naleving door degene die het met de publicaties van het "Committee on Auditing Procedure" niet eens is, sancties kunnen worden toegepast. Dat is slechts mogelijk wanneer deze ,,richtlijnen" als voorschriften deel gaan uitmaken van de „rules of professional conduct". Tot dat stadium is het belangrijkste wat ter verbreiding van de toepassing gedaan kan worden, deze publicaties door woord en geschrift onder de aandacht te brengen van diegenen, die van de arbeid van de accountant gebruik maken. In Amerika is op dat gebied nauw contact met de banken gegroeid.

Schr. vermeldt het resultaat van een onderzoek dat in samenwerking met een 4 tal banken in Detroit werd ingesteld, door een lid van het "Committee on Auditing Procedure" naar de toepassing door accountants in Detroit en omgeving van het in de „Extensions of auditing Procedure" van 1939 gepubliceerde, n.l. ,to observe the taking of inventories and to confirm accounts receivable". Uit dit onderzoek bleek dat slechts in $54 \%$ van de 300 onderzochte rapporten, voldaan was aan het voorschrift betreffende de voorraden en slechts in $45 \%$ aan het voorschrift met betrekking tot de debiteuren. Opgemerkt wordt dat niet bekend is gemaakt, welk deel der 300 bestudeerde rapporten werd uitgebracht door leden van het A.I.A. en dat het alle ondernemingen betrof waarvan de aandelen niet ter beurze werden genoteerd. Naar mijn mening ontnemen deze laatste opmerkingen een deel aan de waarde van dit onderzoek, maar toch kan men het met de schr. eens zijn, dat het resultaat van het onderzoek teleurstellend genoemd kan worden. Vooral de leden die het met de naleving der voorschriften zeer serieus nemen worden door deze gang van zaken benadeeld, het is min of meer een vorm van oneerlijke concurrentie. Het punt heeft in het ",committee" van het A.I.A. dat de samenwerking met de banken behandelt, tot ernstig beraad aanleiding

m a b blz. 23 
gegeven. Over de te nemen maatregelen bestond echter nogal verschil van opinie. Schr. is van mening dat de tijd nog niet gekomen is om deze zaken door de tuchtrechtelijke instantie te doen behandelen, vooral niet omdat gebleken is dat ook bij de banken zelf omtrent deze punten nog veel wanbegrip bestaat. Men is blijkbaar ook in de kringen van de banken nog niet voldoende op de hoogte van de beroepsopvattingen neergelegd in de "Extensions" e.d. geschriften, al verschilt dit plaatselijk nogal. Schrijver is van mening dat van een goed begrip door de banken een sterk stimulerende werking kan uitgaan voor het naleven der „Auditing Standards", door het uitoefenen van druk op de credietnemers om de accountants contrôle op meer doeltreffende wijze te doen plaats vinden.

Teneinde een beter begrip bij de banken voor de verantwoordelijkheid van de accountants en de door deze toegepaste contrôletechnieken te krijgen, is door het ,research department" een geschrift uitgegeven onder de naam , Audits by certified Public Accountants".

Een probleem dat nog bij het ,research department" van het A.I.A. in studie is, is de vraag welke verantwoordelijkheid de accountant dient te dragen voor de mededeling van gebeurtenissen die zich na de balansdatum doch voor de publicatie voor doen. Dit probleem is vooral van belang voor ondernemingen die vallen onder het toezicht van de Securities and Exchange Commission. Door gezaghebbende schrijvers is aan dit probleem in enkele artikelen aandacht besteed. Ik hoop gelegenheid te hebben hierop later terug te komen.

Ook de opeenhoping van werk op de accountantskantoren, tengevolge van het feit dat zeer vele ondernemingen een boekjaar hebben gelijk aan het kalenderjaar, vormt voor de accountant een groot probleem. Verandering van boekjaar schijnt n.l. voor vele ondernemingen ernstige fiscale consequenties te hebben. Schr. is van mening dat men de moeilijkheden aan dit probleem verbonden kan verminderen, door de steekproeven ten aanzien van de goederenvoorraad en de bevestigingen der debiteurensaldi, naar een vroegere datum dan 31 December te verschuiven, b.v. 31 October. Voor grotere ondernemingen geldt dit in mindere mate omdat daar reeds de gewoonte bestaat de voorraden in de loop van het boekjaar op te nemen.

Voor het doorvoeren van deze gedachte geeft schr. de volgende voorwaarden in overweging:

1. Een over een langere periode bestaande relatie met de contrôle-cliënt, gedurende welke de accountant voldoende gelegenheid gehad heeft om te constateren dat:
a. een goed ontwikkeld systeem van interne contrôle bestaat en dat verder;
b. het personeel in de organisatie bekwaamheden bezit, die evenredig zijn aan hun verantwoordelijke posities;
c. bevredigende interne accountantsrapporten aanwezig zijn van het laatste kwartaal van het boekjaar;
d. een redelijk stabiel beeld van zaken in het laatste kwartaal van het jaar bestaat.

2. Een schriftelijke overeenkomst met de cliënt dat het doel van de contrôle niet is het ontdekken van onregelmatigheden.

Schrijver meent dat de accountant die de kleinere ondernemingen controleert (als regel dus ook het kleinere accountantskantoor), op het punt 
van het verschuiven van de einddatum van de contrôle (31 December) naar een vroeger tijdstip, hier mogelijk in het voordeel is. Gewoonlijk toch zal de accountant dan bij gebreke van een voldoende stevige interne contrôle zeer uitgebreide steekproeven nemen om tot een conclusie te kunnen komen. Hierdoor heeft de accountant een nauwkeuriger kennis van de werking van de interne organisatie en de gang van zaken in de onderneming. De grootste moeilijkheid zullen z.i. de middelgrote ondernemingen geven, waar de interne contrôle redelijk goed is, maar nog niet volkomen bevredigend en waar de public accountant lang niet zo'n goed inzicht in de zaak als geheel heeft, als dat bij de kleinere ondernemingen het geval is. Dit alles klinkt m.i. wat "Amerikaans" in onze Hollandse oren.

Het artikel eindigt met enige opmerkingen omtrent de sinds October 1948 bestaande standaard vorm van de korte verklaring, welke volgens schr. aan de verwachtingen voldoet en de mededeling dat binnenkort een studie van het ,research department" van het A.I.A. betreffende de lange verklaring het licht zal zien. 